\section{Evaluation of Slow-release Fertilizers on Bell Pepper}

\author{
Luz M. Reyes ${ }^{1}$, Douglas C. Sanders ${ }^{1,2}$, and Wayne G. Buhler ${ }^{1,3}$
}

AdDITIONAL INDEX wORDs. Capsicum annumm, Nitamin ${ }^{\circledR}$, methylene-urea, fertigation

SuMMARY. This study was conducted to compare different formulations of a slowrelease fertilizer with a conventional fertilizer program to determine their impact on yield and growth of bell pepper (Capsicum annuum). Two formulations of a methylene-urea slow-release fertilizer $\left(\right.$ Nitamin $\left.^{\circledR}\right)$ were evaluated on dripfertigated and plastic-mulched bell peppers during 2006 in the eastern coastal plain and western Appalachian mountains of North Carolina. Liquid slow-release formulations were applied the first 6 or 9 weeks of the growing season and a dry formulation was banded at planting. Treatments were compared with the extension-recommended rate of $200 \mathrm{lb} /$ acre nitrogen $(\mathrm{N})(\mathrm{NC}-200)$ and a high-input fertilizer rate of $300 \mathrm{lb} /$ acre $\mathrm{N}$ (HI-300) from calcium nitrate injected in 12 weekly applications of drip irrigation. Irrigation was applied twice per week. The slow-release granular formulation at $200 \mathrm{lb} /$ acre $\mathrm{N}$ produced the highest marketable yield and better canopy quality in eastern soil. Early marketable yield for this treatment accounted for $46 \%$ of the total yield. All slow-release treatments had higher N use efficiency (NUE) values than NC-200 and HI-300 in the eastern study. In loam soil (western study), pepper yield was statistically similar among treatments. Lower rates $(150 \mathrm{lb} /$ acre $\mathrm{N})$ of slow-release fertilizer performed as well as NC-200 and HI-300 for marketable yield. Low rates (150 lb/acre N) of one of the liquid formulations performed better in total and marketable NUE than NC-200 and HI-300 in Fletcher, North Carolina. Liquid and dry formulations of slow-release fertilizer showed a potential to be used on bell pepper production across the state at reduced $\mathrm{N}$ rates, with greater impact on yield in coarse-textured soils found predominantly in the eastern coastal plain region.

$\mathrm{B}$ est management practices for vegetable production emphasize optimal yields with the least amount of fertilizer to reduce environmental impact. Rainfall and irrigation often leach fertilizer nutrients away from the root zone (Hochmuth, 2003). Various types of slow-release fertilizers may extend the availability of nutrients, especially $\mathrm{N}$, to the plant (Maynard and Lorenz, 1979) and reduce $\mathrm{N}$ leaching losses from soil (Wang and Alva, 1996). Research has been conducted with sulfur-coated urea on vegetables in Florida (Simonne and Hutchinson,

This study was supported by Georgia Pacific Resins, Inc. (Project no. 1115-2007-0173).

Special thanks to Dr. Greg Hoyt, Professor, Soil Science Department, North Carolina State University, and Allan Thornton, Extension Associate, Department of Horticultural Science, North Carolina State University, for their assistance during the development of this study. Appreciation is also expressed to James Wargo, Senior Agronomist, Georgia Pacific Chemicals, LLC, for the review of the manuscript.

${ }^{1}$ Department of Horticultural Science, North Carolina State University, 51 Kilgore Hall, Raleigh, NC 27695

${ }^{2}$ Deceased 17 Apr. 2006

${ }^{3}$ Corresponding author. E-mail: wayne_buhler@ ncsu.edu.
2005); polymer-coated fertilizers on greenhouse/nursery plants (Ristvey and Lea-Cox, 2004) and strawberry (Fragaria spp.; Albregts and Chandler, 1993); and methylene-urea slow-release fertilizers on citrus (Citrus spp.; Zekri and Koo, 1991) and processing tomato (Solanum lycopersicum; Koivunen and Horwath, 2005). Slow-release fertilizer can produce yields at least equal to those observed with split applications of soluble fertilizers in lettuce (Lactuca sativa; Khah and Arvanitoyannis, 2003), tomato (Senthil-Valavan and Kumaresan, 2006), and bell pepper (Wiedenfeld, 1986).

A slow-release methylene-urea polymer-based liquid $\mathrm{N}$ fertilizer, Nitamin ${ }^{\circledR}$ (Georgia Pacific Resins,
Atlanta) releases nitrogen by microbial decomposition (not coated). It is completely water soluble and can be blended with other liquid fertilizers and then used in drip irrigation. The manufacturer claims the urea polymers convert to plant-available forms of $\mathrm{N}$ [i.e., ammonia $\left(\mathrm{NH}_{4}\right)$ and nitrate $\left.\left(\mathrm{NO}_{3}\right)\right]$ over a 60 -d period under most soil conditions. The release rate is affected by microbial activity, and anything that affects soil microorganisms such as soil temperature, oxygen concentration, and water availability has the potential to impact the $\mathrm{N}$ release rate (e.g., the release rate of $\mathrm{N}$ will be slower under cooler soil temperatures). No minimum soil temperature is required, and there does not appear to be a delay in $\mathrm{N}$ release after soil fumigation because of the rapid buildup of microorganisms shortly after fumigation and before the start of fertilizer injections (J. Wargo, unpublished data)

The objective of this study was to compare the effectiveness of two formulations of slow-release fertilizers under drip irrigation and applied at different rates with conventional fertilizer programs for bell pepper production. Experiments were conducted in two regions of North Carolina on two different soil types. Yield and fruit quality were examined.

\section{Materials and methods}

Field study. Studies were established on drip-fertigated and plasticmulched bell peppers during 2006 in the coastal plain (eastern region) and the western Appalachian Mountains of North Carolina. Experiments were conducted at the Horticultural Crops Research Station in Clinton, North Carolina (lat. $35^{\circ} \mathrm{N}$, long. $78.3^{\circ} \mathrm{W}$, altitude $158 \mathrm{ft}$ ), and at the Mountain Horticultural Crops Research and Extension Center in Fletcher, North Carolina (lat. $35.4^{\circ} \mathrm{N}$, long. $82.5^{\circ} \mathrm{W}$, altitude $2067 \mathrm{ft}$ ). Bed dimensions

\begin{tabular}{llll}
\hline $\begin{array}{l}\text { Units } \\
\text { To convert U.S. to SI, } \\
\text { multiply by }\end{array}$ & U.S unit & SI unit & $\begin{array}{l}\text { To convert SI to U.S., } \\
\text { multiply by }\end{array}$ \\
\hline 100 & $\mathrm{bar}$ & $\mathrm{kPa}$ & 0.01 \\
0.3048 & $\mathrm{ft}$ & $\mathrm{m}$ & 3.2808 \\
2.54 & inch $(\mathrm{es})$ & $\mathrm{cm}$ & 0.3937 \\
0.4536 & $\mathrm{lb}$ & $\mathrm{kg}$ & 2.2046 \\
1.1209 & $\mathrm{lb} / \mathrm{acre}$ & $\mathrm{kg} \cdot \mathrm{ha}^{-1}$ & 0.8922 \\
0.0254 & $\mathrm{mil}$ & $\mathrm{mm}$ & 39.3701 \\
$\left({ }^{\circ} \mathrm{F}-32\right) \div 1.8$ & ${ }^{\circ} \mathrm{F}$ & ${ }^{\circ} \mathrm{C}$ & $\left(1.8 \times{ }^{\circ} \mathrm{C}\right)+32$
\end{tabular}


were 8 in high $\times 5 \mathrm{ft}$ wide, and beds were pressed and covered with polyethylene black plastic mulch (1.25 $\mathrm{mm}$ thick). Drip irrigation tubes (standard 5/8-inch drip tape) were installed $l$ inch deep in the bed center under the mulch film. Drip irrigation was used to establish the crop and to maintain soil moisture at $-25 \mathrm{kPa}$ or greater to a 6-inch depth. Recommended production practices for fresh-market bell peppers were followed (Sanders, 2006). Bell pepper cultivars were chosen for this experiment based on differences in the soil characteristics at the two sites. Soil temperatures were not recorded.

'Heritage' peppers were planted in a loamy sand soil (Norfolk fineloamy, siliceous thermic Typic Paleudults) in Clinton. The average monthly and total rainfall during the 2006 growing season was 3.25 and 15.71 inches, respectively, with an average temperature of $71.2^{\circ} \mathrm{F}$ (April to July). Seedlings about 3 inches tall were mechanically planted in double rows spaced 12 inches apart on beds $30 \mathrm{ft}$ long on 18 Apr.

'Aristotle' peppers were planted in a fine sand loam soil (Comus fineloamy, mixed mesic Fluventic Dystrochrepts) in Fletcher. The average monthly and total rainfall during the
2006 growing season was 4.96 and 26.28 inches, respectively, with an average temperature of $69.9^{\circ} \mathrm{F}$ (June to September). Seedlings about 3 inches tall were manually planted in double rows spaced 12 inches apart on beds $30 \mathrm{ft}$ long on 22 June.

A block design was used with eight treatments and five replicates in Clinton and four replicates in Fletcher (Table 1). Granular and liquid methylene urea formulations were investigated. The treatments included a granular formulation (G43 ) consisting of $43 \%$ water-soluble $\mathrm{N}$ with $30 \%$ of the $\mathrm{N}$ in the form of methylene urea polymers and 70\% urea. Additional liquid treatment formulations consisted of a $5 \% \mathrm{~N}$ formulation (L-5) and a $30 \% \quad \mathrm{~N}$ formulation (L-30) with $60 \%$ of the $\mathrm{N}$ as methylene urea polymers and $40 \%$ of the $\mathrm{N}$ as urea. All treatments received $500 \mathrm{lb}$ of $10 \mathrm{~N}-4.4 \mathrm{P}-16.6 \mathrm{~K}$ preplant fertilizer to provide $50 \mathrm{lb} /$ acre $\mathrm{N}$ from ammonium nitrate $\left(\mathrm{NH}_{4} \mathrm{NO}_{3}\right), 50 \mathrm{lb} /$ acre phosphorous (P) from ammonium phosphate $\left[\left(\mathrm{NH}_{4}\right)_{3} \mathrm{PO}_{4}\right]$, and $100 \mathrm{lb} /$ acre potassium $(\mathrm{K})$ from potassium chloride $(\mathrm{KCl})$. Preplant fertilizer accounted for the increase of $50 \mathrm{lb} /$ acre $\mathrm{N}$ in total $\mathrm{N}$ applied for all treatments. G-43 was applied in a band at rates of 100 and $150 \mathrm{lb} /$ acre $\mathrm{N}$ about 3 inches below the soil surface and 15 inches from the center of the plot before the plastic mulch was installed. L-5 was applied at $150 \mathrm{lb} /$ acre $\mathrm{N}$ in Clinton and $100 \mathrm{lb} /$ acre $\mathrm{N}$ in Fletcher because of differences in soil texture between these sites. L-30 was applied at 100 and $150 \mathrm{lb} /$ acre $\mathrm{N}$ at both sites. A combination treatment that included $\mathrm{L}-30$ and $\mathrm{KNO}_{3}$ was applied at $150 \mathrm{lb} /$ acre $\mathrm{N}$ in Clinton and $100 \mathrm{lb} /$ acre $\mathrm{N}$ in Fletcher. In this treatment, only $40 \%$ of the $\mathrm{N}$ came from L-30, with the remaining $\mathrm{N}$ from potassium nitrate $\left(\mathrm{KNO}_{3}\right)$. It received the same preplant fertilizer as was applied to the other treatments. Adjustments were made to balance the $\mathrm{K}$ supplied by $\mathrm{KNO}_{3}$. L-30 and L-5 treatments were applied weekly, starting 3 WAT, through drip irrigation over a 6- and 9-week period, respectively. Two conventional fertilizer treatments (a mix of potassium nitrate and calcium nitrate) were injected during the season to supply 150 or $250 \mathrm{lb} /$ acre $\mathrm{N}$ for total $\mathrm{N}$ rates of $200(\mathrm{NC}-200)$ and $300 \mathrm{lb} /$ acre $\mathrm{N}$ (HI-300). The extension recommended $\mathrm{N}$ rate is $200 \mathrm{lb} /$ acre $\mathrm{N}$ (Sanders, 2006) and reflects the $\mathrm{N}$ rate typically used by commercial bell pepper growers in North Carolina.

Table 1. Fertilizer treatments applied on bell pepper at two locations in North Carolina.

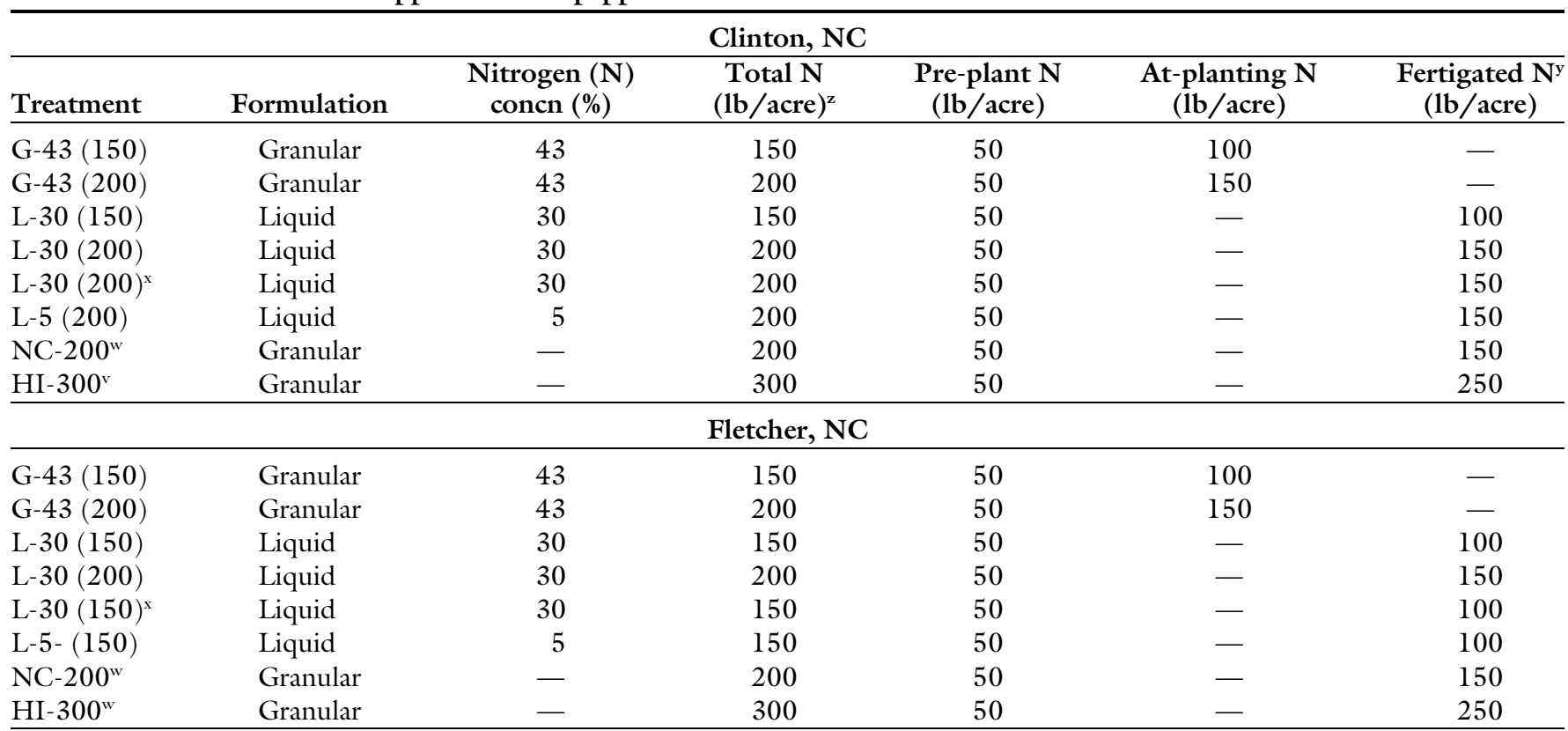

${ }^{\mathrm{z}} \mathrm{l} \mathrm{lb} / \mathrm{acre}=1.1209 \mathrm{~kg} \cdot \mathrm{ha}^{-1}$

${ }^{y} \mathrm{~L}-30$ and L-5 treatments were applied weekly starting 3 weeks after transplanting (WAT) through drip irrigation over 6- and 9-week periods, respectively. NC-200 and HI-300 were applied via fertigation for a 12 -week period starting 3 WAT.

${ }^{\mathrm{x}}$ Combination treatment containing $\mathrm{L}-30$ and potassium nitrate $\left(\mathrm{KNO}_{3}\right)$, where $40 \%$ of the $\mathrm{N}$ came from $\mathrm{L}-30$ and $60 \%$ came from $\mathrm{KNO}_{3}$. Adjustments were made to balance for potassium supplied by $\mathrm{KNO}_{3}$

${ }^{\mathrm{w}} \mathrm{NC}=$ North Carolina extension-recommended $\mathrm{N}$ rate, $\mathrm{HI}=$ high-input $\mathrm{N}$ rate 
The conventional treatments were applied via fertigation for a 12-week period starting 3 WAT. Potassium sources $\left(\mathrm{KCl}\right.$ or $\left.\mathrm{KNO}_{3}\right)$ were added to granular and liquid fertilized plots through the drip tube to keep the ratio of $1 \mathrm{~N}: 0 \mathrm{P}: 2 \mathrm{~K}$ from the beginning of the study until the 12th week. Potassium fertilizer rates were based on soil test results taken before planting. Weekly irrigation and fertigation were applied using independent lines for each treatment.

Plant Quality and yield MEASUREMENTS. Bell pepper plants were rated twice during the season at 4 and 8 WAT, according to vigor, canopy shade, and overall quality in the eastern experiment (Clinton). Categories were established based on the following scale: $1=$ very good stand $(100 \%$ growing plants, $100 \%$ canopy shade); 2 = good stand $(90 \%$ growing plants, $90 \%$ canopy shade); and, $3=$ fair stand $(80 \%$ growing plants, $80 \%$ canopy shade). These data were transformed to square roots before statistical analysis. Bell peppers were harvested three times at 1 -week intervals at both sites. Mature fruit from 20 of 60 plants were harvested from the center of each plot. Fruit number and weight per plot and per class were recorded. Bell peppers were mechanically sized and graded into U.S. Fancy, U.S. No. 1, and unmarketable according to the U.S. Standards for Grades of Sweet Peppers (U.S. Department of Agriculture, 2005). Cull grade consisted of fruit that were misshapen or damaged by insects or diseases. Early marketable yield (the first harvest), total marketable yield, cull yield, and total yield were recorded. Nitrogen use efficiency (NUE) is defined as the number of pounds of fruit produced by each pound of added $\mathrm{N}$ (Hutchinson et al., 2003). In this study, NUE was calculated by dividing the total yield and marketable yield by the $\mathrm{N}$ rate (lb/acre) for each treatment.

The General Linear Models procedure of analysis of variance in SAS (version 9.1; SAS Institute, Cary, $\mathrm{NC}$ ), was used to test differences between treatments. Treatments means were separated using the Fisher's protected least significant difference (LSD) test. Data from each location were analyzed independently because of differences in cultivar, planting time, and environmental conditions.

\section{Results and discussion}

Clinton. Statistical differences among treatments were found for total, marketable, and early marketable yield at the Clinton site (Table 2). G-43 (150 lb/acre N), L-30 (150 $\mathrm{lb} /$ acre N), and NC-200 produced the lowest total and marketable yield. These treatments had statistically lower yield than G-43 (200 lb/acre $\mathrm{N}$ ), which produced the highest yield. All slow-release treatments (granular and liquid) at $200 \mathrm{lb} /$ acre $\mathrm{N}$ produced $17 \%$ to $38 \%$ more total yield than NC-200. Early marketable yield for L-30 and G-43 at $200 \mathrm{lb} /$ acre N accounted for $44 \%$ and $46 \%$, respectively, of the total yield. No significant differences among treatments were detected during second or third harvests.
No statistical differences were found among fruit size classes. U.S Fancy bell peppers were the main contributors of marketable yield in this study. The percentage of culls was generally low across all treatments (Table 2). The most frequent reason for culling fruit was sunscald. Sunscald occurs when fruit are exposed to high levels of sunlight, probably because of a poor foliage cover (Roberts and Anderson, 1994). Canopy shade was poorest with treatment G43 (150 lb/acre N; Table 2). NUE values for all slow-release treatments were higher and, in some cases, significantly different from the conventional fertilizer treatments (Table 3 ). L-30 (150 lb/acre N) and G-43 (200 $\mathrm{lb} /$ acre N) differed by more than 53 $\mathrm{lb}$ of fruit per pound of fertilizer compared with NC-200. This suggests that more $\mathrm{N}$ was made available by slow-release fertilizers to meet the needs of the plant for growth and fruit production. Similar results have been reported for slow-release fertilizers on potato (Solanum tuberosum; Hutchinson et al., 2003) and tomato (Koivunen and Horwath, 2005).

Fletcher. No significant differences were detected between treatments in total and marketable yields, fruit size, and percentage of cullage (data not shown). The low rate of slow-release fertilizers performed as well as NC-200, probably because of the better retention of water and nutrients in loam soil at this location. Ristimaki (2000) reported similar results in fertigated onion (Allium cepa), tomato, and watermelon (Citrullus lanatus), with equal or slightly

Table 2. Effect of fertilizer treatments on pepper yield and plant quality at Clinton, NC.

\begin{tabular}{|c|c|c|c|c|c|c|}
\hline Treatment $^{\mathrm{z}}$ & $\begin{array}{l}\text { Total yield } \\
(\text { lb/acre })^{y}\end{array}$ & $\begin{array}{c}\text { Marketable } \\
\text { yield } \\
(\text { lb } / \text { acre })\end{array}$ & $\begin{array}{c}\text { Early marketable } \\
\text { yield } \\
\text { (lb/acre })\end{array}$ & $\begin{array}{l}\text { U.S. fancy } \\
\text { grade } \\
\text { (lb/acre) }\end{array}$ & Culls (\%) & $\begin{array}{c}\text { Canopy shade } \\
(1-3 \text { scale })^{\mathrm{x}} \\
\end{array}$ \\
\hline G-43 (150) & $23,375 \mathrm{c}$ & $21,675 \mathrm{c}$ & $6,800 \mathrm{c}$ & 17,550 & 8.2 & $2.2 \mathrm{a}$ \\
\hline L-30 (150) & $29,150 \mathrm{bc}$ & $27,600 \mathrm{bc}$ & $10,775 \mathrm{bc}$ & 21,250 & 5.6 & $1.5 \mathrm{bc}$ \\
\hline L-30 (200) & $33,350 \mathrm{ab}$ & $31,750 \mathrm{ab}$ & $14,525 \mathrm{ab}$ & 26,400 & 4.7 & $1.1 \mathrm{c}$ \\
\hline NC-200 & $27,975 \mathrm{bc}$ & $26,075 \mathrm{bc}$ & $8,875 \mathrm{c}$ & 21,050 & 7.5 & $1.6 \mathrm{~b}$ \\
\hline HI-300 & $32,725 \mathrm{ab}$ & $31,000 \mathrm{ab}$ & $11,350 \mathrm{bc}$ & 25,875 & 5.3 & $1.3 \mathrm{bc}$ \\
\hline Significance & * & * & * & NS & NS & $* *$ \\
\hline
\end{tabular}

${ }^{2}$ Refer to Table 1 for explanation of treatment codes.

${ }^{\mathrm{l}} \mathrm{l} \mathrm{lb} / \mathrm{acre}=1.1209 \mathrm{~kg} \cdot \mathrm{ha}^{-1}$.

${ }^{\mathrm{x}} 1$ = excellent, 2 = good, 3 = fair. Data were transformed with square root before analysis of variance; nontransformed values are presented

${ }^{w}$ Combination treatment containing L-30 and potassium nitrate $\left(\mathrm{KNO}_{3}\right)$, where $40 \%$ of the nitrogen came from $\mathrm{L}-30$ and $60 \%$ came from $\mathrm{KNO}$. Adjustments were made to balance for potassium supplied by $\mathrm{KNO}_{3}$

Ns, ${ }^{*},{ }^{* *}$ Not significant or significant at $P<0.05$ and $P<0.01$, respectively. Treatment means were separated with Fisher's protected least significant difference test. 
Table 3. NUE for total and marketable pepper yield at Clinton, NC.

\begin{tabular}{llc}
\hline Treatment $^{\mathbf{z}}$ & $\begin{array}{c}\text { NUE } \\
\text { total } \\
\text { yield }^{\mathbf{y}}\end{array}$ & $\begin{array}{c}\text { NUE } \\
\text { marketable } \\
\text { yield }^{\mathbf{y}}\end{array}$ \\
\hline G-43 (150) & $156 \mathrm{ab}$ & $144 \mathrm{abc}$ \\
G-43 (200) & $193 \mathrm{a}$ & $183 \mathrm{a}$ \\
L-30 (150) & $194 \mathrm{a}$ & $184 \mathrm{a}$ \\
L-30 (200) & $167 \mathrm{ab}$ & $159 \mathrm{ab}$ \\
L-30 (200) & $169 \mathrm{ab}$ & $160 \mathrm{ab}$ \\
L-5- $(200)$ & $164 \mathrm{ab}$ & $157 \mathrm{ab}$ \\
NC-200 & $140 \mathrm{bc}$ & $130 \mathrm{bc}$ \\
HI-300 & $109 \mathrm{c}$ & $103 \mathrm{c}$ \\
\hline
\end{tabular}

${ }^{2}$ Refer to Table 1 for explanation of treatment codes. yNUE was calculated by dividing the total yield or marketable yield by the nitrogen $(\mathrm{N})$ rate (lb/acre) for each treatment. Treatment means were separated with Fisher's protected least significant difference test at $P<0.05\left(1 \mathrm{lb} /\right.$ acre $\left.=1.1209 \mathrm{~kg} \cdot \mathrm{ha}^{-1}\right)$.

Combination treatment containing L-30 and potassium nitrate $\left(\mathrm{KNO}_{3}\right)$, where $40 \%$ of the $\mathrm{N}$ came from L-30 and $60 \%$ came from $\mathrm{KNO}_{3}$. Adjustments were made to balance for potassium supplied by $\mathrm{KNO}_{3}$.

higher yields using methylene-urea slow-release fertilizer. U.S. Fancy bell peppers were the main contributor to yield, which represented at least $60 \%$ of the marketable yield in all treatments. The percentage of fruit rated culls was generally low $(4.6 \%-8.3 \%)$ among treatments.

NUE values for all low rate ( 150 $\mathrm{lb} /$ acre $\mathrm{N}$ ) slow-release liquid treatments were higher and, in some cases, significantly different from the conventional fertilizer treatments for total and marketable yield (Table 4 ). L-30 (150 lb/acre $\mathrm{N}$ ) treatments differed by more than $64 \mathrm{lb}$ of fruit per lb of fertilizer compared with NC200. Marketable NUE values for NC200 and HI-300 were low, at 190 and 132 , respectively.

\section{Conclusions}

The performance of slow-release formulations used in this study varied by location. Although all slow-release treatments resulted in higher NUE values than the conventional fertilizer treatments in eastern soil, G-43 (200 $\mathrm{lb} /$ acre $\mathrm{N}$ ) provided consistently superior results in virtually all yield and plant quality measures. This formulation's attribute of promoting a robust early marketable yield could contribute largely to a grower's objective of gaining maximum net returns. The additional benefit of an
Table 4. NUE for total and marketable yield at Fletcher, NC.

\begin{tabular}{lll}
\hline Treatment $^{\mathbf{z}}$ & $\begin{array}{c}\text { NUE } \\
\text { total } \\
\text { yield }^{\mathbf{y}}\end{array}$ & $\begin{array}{c}\text { NUE } \\
\text { marketable } \\
\text { yield }^{\mathbf{y}}\end{array}$ \\
\hline G-43 $(150)$ & $251 \mathrm{ab}$ & $236 \mathrm{abc}$ \\
G-43 $(200)$ & $180 \mathrm{c}$ & $165 \mathrm{~d}$ \\
L-30 $(150)$ & $274 \mathrm{a}$ & $254 \mathrm{a}$ \\
L-30 $(200)$ & $193 \mathrm{bc}$ & $184 \mathrm{~cd}$ \\
L-30 $(150)^{\mathrm{x}}$ & $274 \mathrm{a}$ & $262 \mathrm{a}$ \\
L-5- $(150)$ & $269 \mathrm{a}$ & $251 \mathrm{ab}$ \\
NC-200 & $200 \mathrm{bc}$ & $190 \mathrm{bcd}$ \\
HI-300 & $139 \mathrm{c}$ & $132 \mathrm{~d}$
\end{tabular}

${ }^{\mathrm{z}}$ Refer to Table $\mathrm{l}$ for explanation of treatment codes. ${ }^{y}$ NUE was calculated by dividing the total yield or marketable yield by the nitrogen $(\mathrm{N})$ rate (lb/acre) for each treatment. Treatment means were separated with Fisher's protected least significant difference test at $P<0.01$ ( $1 \mathrm{lb} /$ acre $=1.1209 \mathrm{~kg} \cdot \mathrm{ha}^{-1}$ ).

${ }^{x}$ Combination treatment containing L-30 and potassium nitrate $\left(\mathrm{KNO}_{3}\right)$, where $40 \%$ of the $\mathrm{N}$ came from $\mathrm{L}-30$ and $60 \%$ came from $\mathrm{KNO}_{3}$. Adjustments were made to balance for potassium supplied by $\mathrm{KNO}_{3}$.

at-planting time application of this granular material eliminates the fertigation costs associated with liquid formulations. The distinctions between $\mathrm{N}$ source and rate were not as clear in the western experiment (Fletcher). In terms of NUE, the low rates of the slow-release liquid treatments produced better results than those produced by the conventional fertilizer treatments. Application of low rates of $\mathrm{N}$ will minimize the content of residual nitrates and reduce the potential for nonpoint source pollution. The integration of slow-release fertilizer with plasticulture and drip irrigation will contribute to the implementation of best management practices for bell pepper production in conditions similar to this study.

\section{Literature cited}

Albregts, E.E. and C.K. Chandler. 1993. Slow release rates for strawberry production. Proc. Florida State Hort. Soc. 106:187-189.

Hochmuth, G.J. 2003. Progress in mineral nutrition and nutrient management for vegetables in the last 25 years. HortScience 38:999-1003.

Hutchinson, C., E. Simonne, P. Solano, J. Meldrum, and P. Livingston-Way. 2003 Testing of controlled release fertilizer programs for seep irrigated irish potato production. J. Plant Nutr. 26:1709-1723.
Khah, E.M. and I.S. Arvanitoyannis. 2003. Effect of fertilizers on lettuce ( $L a c$ tuca sativa) yield, physical and organoleptic properties. Adv. Hort. Sci. 17:4757.

Koivunen, M.E. and W.R. Horwath. 2005. Methylene urea as a slow-release nitrogen source for processing tomatoes. Nutrient Cycling Agroecosystems 71: 177-190

Maynard, D.N. and O.A. Lorenz. 1979. Controlled-release fertilizers for horticultural crops. Hort. Rev. (Amer. Soc. Hort. Sci.) 1:79-140.

Ristimaki, L.M. 2000. Slow release fertilizers on vegetables. Acta Hort. 511:125131.

Ristvey, A.G. and J.D. Lea-Cox. 2004. Nutrient uptake, partitioning and leaching losses from container-nursery production systems. Acta Hort. 630:321-328.

Roberts, B.W. and J.A. Anderson. 1994. Canopy shade and soil mulch affect yield and solar injury of bell pepper. HortScience 29:258-260.

Sanders, D.C. (ed.). 2006. Vegetable crop handbook for the southeastern U.S. North Carolina Veg. Growers Assn., Raleigh, NC.

Senthil-Valavan, P. and K.R. Kumaresan. 2006. Relative efficiency of controlled release and water soluble fertilizers on the yield and quality of tomato (Lycopersicon esculentum Mill.). J. Agron. 5:519522.

Simonne, E.H. and C.M. Hutchinson. 2005. Controlled-release fertilizer for vegetable production in the era of best management practices: Teaching new tricks to an old dog. Hort Technology $15: 36-46$.

U.S. Department of Agriculture. 2005. U.S. standards for grades of sweet peppers. 8 Feb. 2008. <http://www.ams. usda.gov/standards/sweetpeppers.pdf $>$.

Wang, F.L. and A.K. Alva. 1996. Leaching of nitrogen from slow-release urea sources in sandy soils. Soil Sci. Soc. Amer. J. 60:1454-1458.

Wiedenfeld, R.P. 1986. Rate, timing and slow-release nitrogen fertilizers on bell peppers and muskmelon. HortScience 21:233-235.

Zekri, M. and R.C.J. Koo. 1991. Evaluation of controlled-release fertilizer for young citrus trees. J. Amer. Soc. Hort. Sci. 116(6):897-990. 